\title{
Ti-Ni 形状記憶合金溶接部の形状回復及び引張特性に及ぼす窒素の影響*
}

\author{
- Ti-Ni 形状記憶合金の GTA 溶接に関する研究（第 2 報）一
}

佐藤 嘉洋**, 粉川 博之***, 桑名 武****, 佐藤 正一*****, 佐藤 裕 ${ }^{* * *}$

\author{
Effect of Nitrogen on Shape Recovery and Tensile Properties of Ti-Ni Alloy Weldments* \\ -GTA Welding of Ti-Ni Shape Memory Alloy (Report 2) -
}

\author{
by Yoshihiro SATO**, Hiroyuki KOKAWK ${ }^{* * *}$, Takeshi KUWANA****, Shouichi SATO***** \\ and Yutaka S. SATO***
}

\begin{abstract}
Effects of nitrogen on microstructure, shape recovery behavior and tensile property of $\mathrm{Ti}-\mathrm{Ni}$ alloy weldments were investigated. A near-equiatomic $\mathrm{Ti}-\mathrm{Ni}$ shape memory alloy was welded by a gas tungsten arc (GTA) welding technique under Ar $-\mathrm{N}_{2}$ welding atmosphere. The nitrogen absorbed into the weld metal increased with rising nitrogen partial pressure and welding current. Second phase particles were observed in the weld metal containing nitrogen. The second phase was identified as TiN by transmission electron microscopy. The shape recovery stress of the weldment was equivalent to that of the base material. As temperature of the weld metal decreased with increasing nitrogen content. Tensile strength of the alloy decreased by welding process, and the further reduction was observed for the weld metal absorbed nitrogen. Elongation also decreased by welding and rising nitrogen content.
\end{abstract}

Key Words : GTA welding, Ti-Ni shape memory alloy, nitrogen content, TiN second phase, shape recovery stress, mechanical property.

\section{1. 緒言}

前報》では，Ti-Ni 合金 GTA 溶接部の形状回復及び引 張特性に及ぼす酸素の影響について検討した.この合金は， 形状記憶特性などの特異な機能性を持つために, 各種用途 に応用2)され始めているが，溶融状態でガス成分と反応 し易いにも拘わらずがス成分の影響ついての検討は未だ十 分とは言えないからである。本研究では，前報1に引き続き 窒素の影響について検討する，窒素は，酸素とともに溶接 過程で材料に及ぼす影響が大きいがス成分と考えられてい る.しかし, 窒素が $\mathrm{Ti}-\mathrm{Ni}$ 合金溶接部の形状回復及び引張 特性に及ぼす影響について系統的に調べた報告はほとんど 見あたらないのが現状である．また，この合金の変態温度 などの機能特性に及ぼす窒素の影響についても著者らの研 究4) 以外にはほとんど見あたらない.従って,この合金の溶 融を伴う接合法の基礎的データとして酸素と同様に, 窒素

\footnotetext{
*原稿受付 平成 10 年 7 月 16 日 平成 8 年11月 $6 \mathrm{WS}$ で発表

**正 員 大阪市立大学工学部 Member, Osaka City University, Faculty of Eng.

***正貝東北大学大学院工学研究科 Member, Tohoku Univ., Graduate School of Eng.

****正 員 東北大学名誉教授 Member, Honorary Professor of Tohoku Univ.

(侏トーキン Tokin Corp.
}

との反応挙動, 並びに諸特性に及ぼす窒素の影響について 明らかにしておくことが，是非とも必要である。

そこで本研究では，酸素の影響とを調べた前報 ${ }^{1)}$ と同様 な方法を用いて $\mathrm{Ti}-\mathrm{Ni}$ 形状記憶合金を $\mathrm{Ar}-\mathrm{N}_{2}$ 雾囲気でガ ス・タングステン・アーク（GTA）溶接し, $\mathrm{Ti}-\mathrm{Ni}$ 溶融金 属の窒素吸収挙動を調べ，金属組織，形状記憶特性及び接 合部の機械的性質に及ぼす窒素の影響について検討する.

\section{2. 実 験 方 法}

供試材料及び実験装置は, 前報1)と同じである. 供試材料 の化学組成を Table 1 に示すが, 等原子比組成に近い Ti$49.7 \mathrm{~mol} \%$ (at.\%) Ni 合金である. 溶接雲囲気は $\mathrm{Ar}-\mathrm{N}_{2}$ 混 合ガスであり, 全圧 $\left(p_{\mathrm{Ar}}+p_{\mathrm{N}_{2}}\right)$ を0.1 MPa一定として窒素 分圧 $\left(p_{\mathrm{N}_{2}}\right)$ を 0 0.02 $\mathrm{MPa}$ に変化させた. 溶接条件は, 溶 接電流を40～ $80 \mathrm{~A}$ に変化させる以外前報 ${ }^{1)}$ と同じである. 溶接金属の窒素量は, 不活性ガス融解ガスクロマトグラフ 法 (IECO 社製) で測定した. 溶接部の組織観察, 形状回復

Table 1 Chemical composition of base material (mass\%).

\begin{tabular}{|c|c|c|c|c|c|}
\hline & $\mathrm{O}$ & $\mathrm{C}$ & $\mathrm{N}$ & $\mathrm{Ni}$ & $\mathrm{Ti}$ \\
\hline Base material & 0.0501 & 0.0460 & 0.0034 & 54.72 & Bal. \\
\hline
\end{tabular}


力測定および引張試験が行ったが, 前報 ${ }^{1)}$ と同様な試験片 を用いてほぼ同様な方法で行った。

\section{3. 実験結果および考察}

\section{1 窒素吸収挙動}

$\mathrm{Ti}-\mathrm{Ni}$ 合金の窒素吸収挙動を調べるために，窒素分压

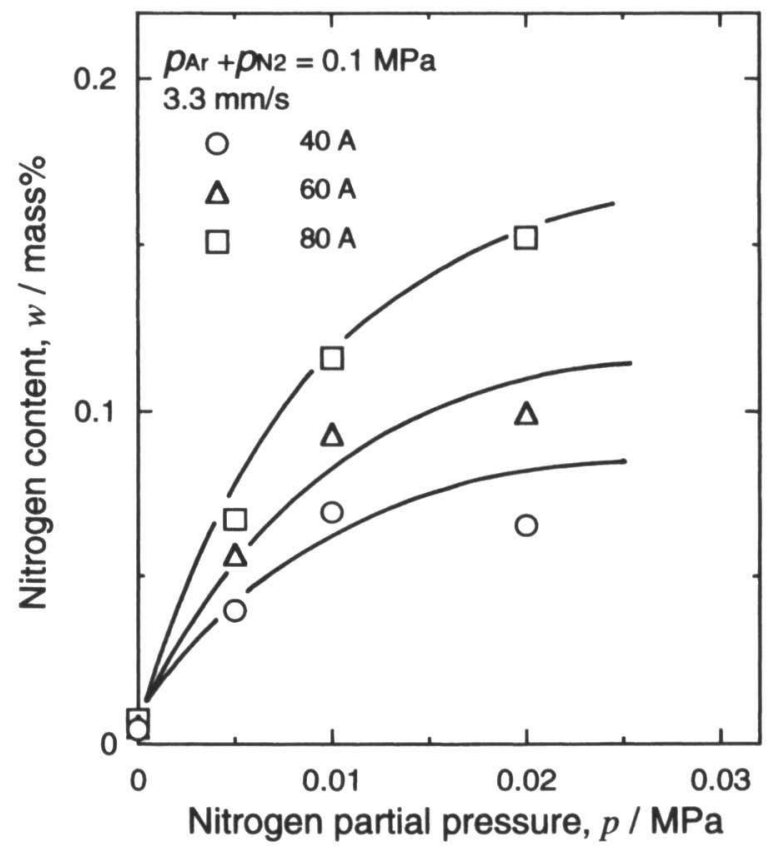

Fig. 1 Nitrogen content of weld metal in $\mathrm{Ar}-\mathrm{N}_{2}$ welding atmosphere.
$\left(p_{\mathrm{N}_{2}}\right)$ を 0 0.02 MPa，溶接電流を40〜80 A 範囲で変化 させて溶接を行い，溶接金属中の窒素量を調べた結果を Fig. 1 に示す. 窒素分圧及び溶接電流の増加とともに, 溶接 金属の窒素量は増加する. 溶接電流の増加により窒素量が 増加するのは, 溶接電流が増加すると溶接ビード幅が広く なる傾向があり，雾囲気ガスと溶融金属との反応比表面積 が広くなるためであり，酸素を吸収する場合 ${ }^{1)}$ と同様に考 えられる.

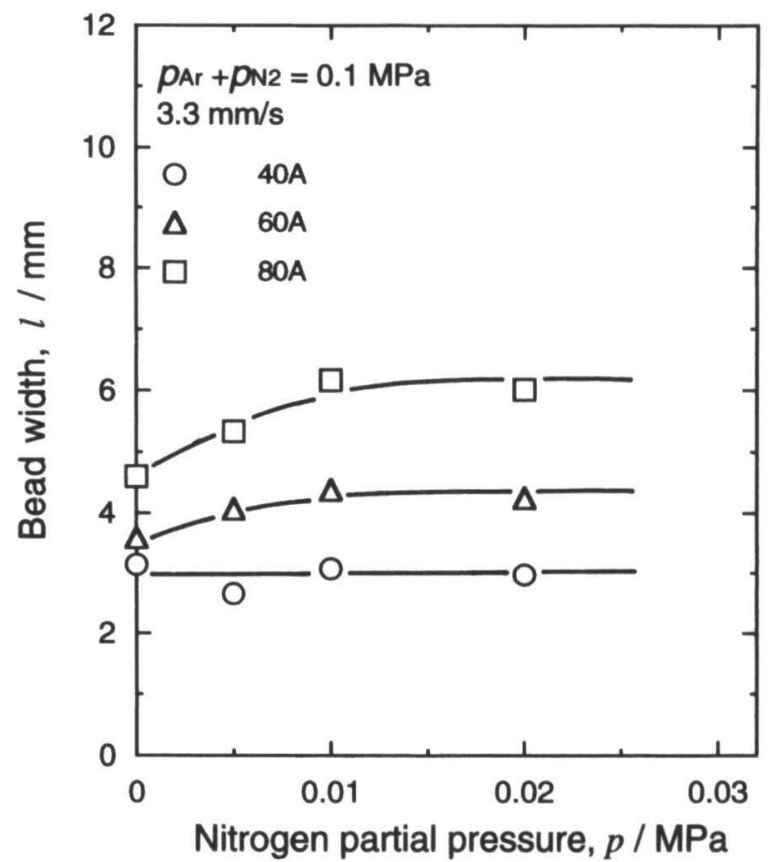

Fig. 2 Width of weld bead as a function of nitrogen partial pressure and welding current.

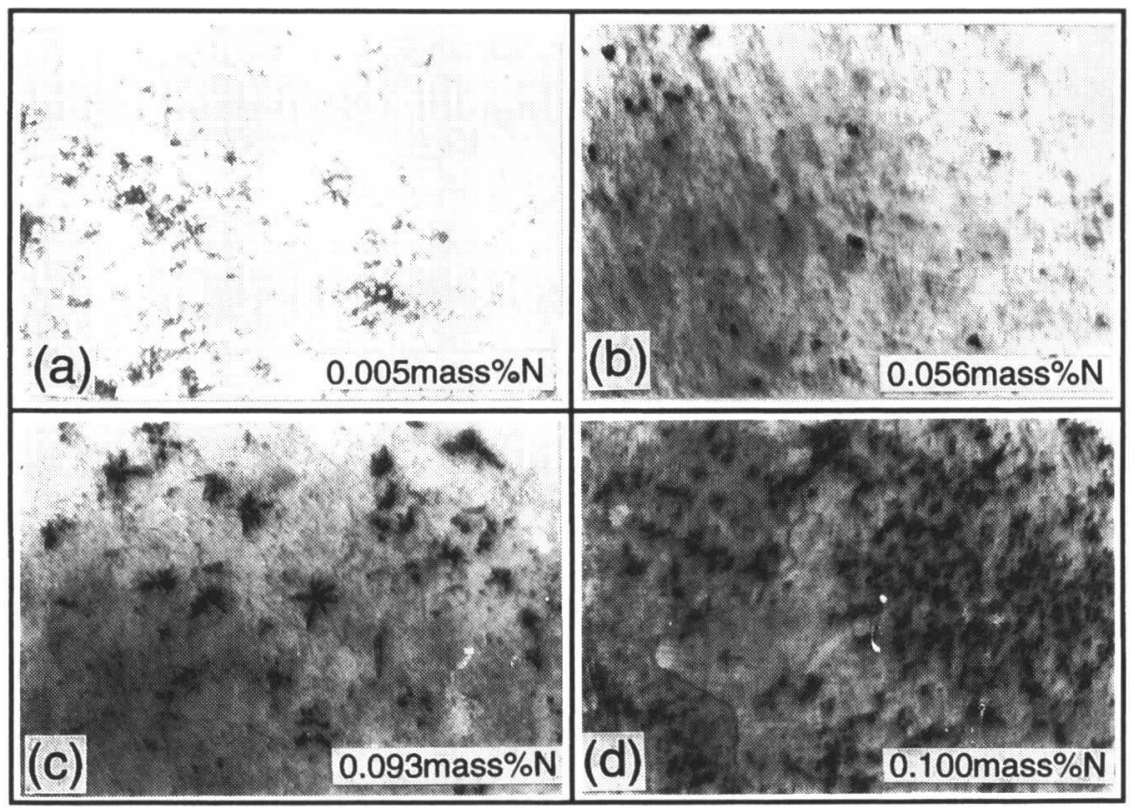

$50 \mu \mathrm{m}$
Fig. 3 Microstructure of weld metal in $\mathrm{Ar}-\mathrm{N}_{2}$ welding atmosphere $(60 \mathrm{~A})$

(a) 0.005 mass $\% \mathrm{~N}, \quad$ (b) 0.056 mass $\% \mathrm{~N}$, (c) $\quad 0.093$ mass $\% \mathrm{~N}$, and (d) 0.10 mass $\% \mathrm{~N}$. 


\section{2 溶接ビード形状および金属組織}

溶接ビード幅を調べた結果を Fig. 2 に示す。ビード幅は 溶接電流が増加すると広くなり，雾囲気の窒素分圧が増加 すると増加する傾向を示し，およそ3〜 6 mmである。ま た，溶接金属にブローホールなどの溶接欠宿は観察されな かった，ビード断面のマクロ組織を観察すると，溶融境界 部から柱状的な結晶が成長し，ビード中央部では粗大で等 軸的な結晶粒組織であった。これは，前報1)の $\mathrm{Ar}-\mathrm{O}_{2}$ 雾囲 気の場合と同様な結果である。窒素量が異なる溶接金属の ミクロ組織を Fig. 3 に示す。Fig. 3 (a)から(d)への順に窒素 量が増加している。溶接金属が窒素を吸収すると黒いコン トラストで示される第二相が観察され始め，窒素量が増加 するとともに，この第二相の量は増加する. Fig. 4 に, この
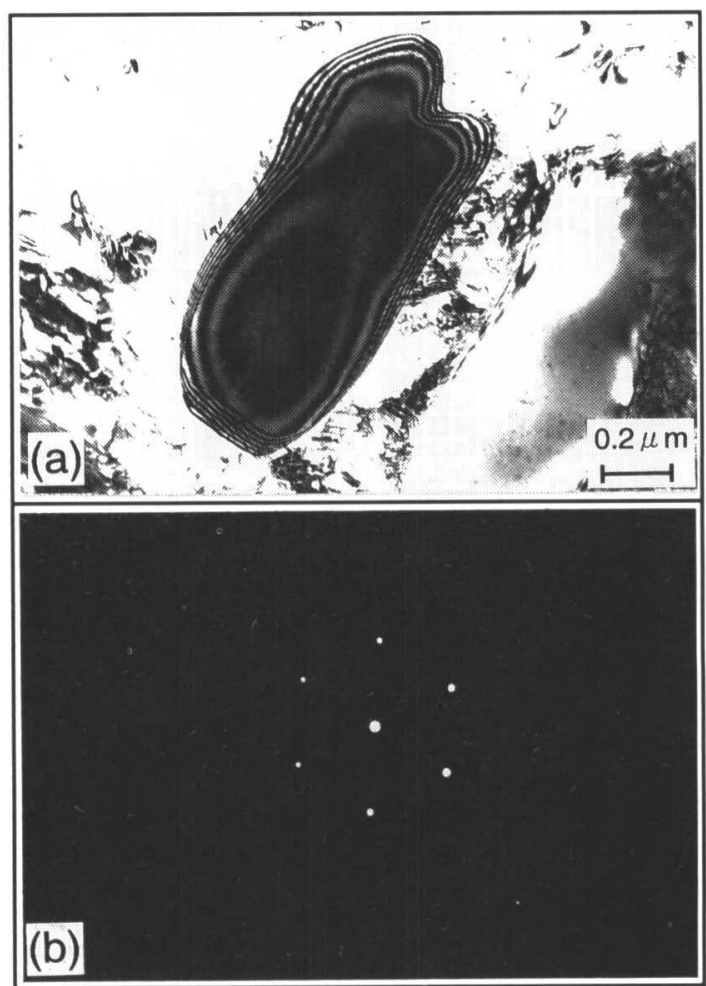

(c)

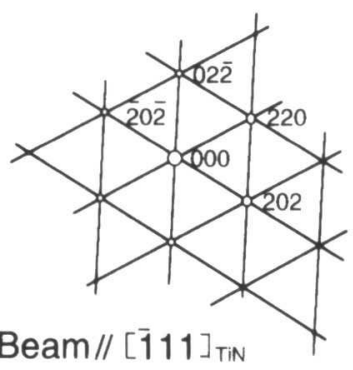

Fig. 4 TEM image of second phase in weld metal $\left(p_{\mathrm{N}_{2}}=0\right.$. $020 \mathrm{MPa}, 60 \mathrm{~A}$ )

(a) bright field image, (b) electron diffraction pattern, and (c) key diagram.
第二相を TEM 観察した結果を示す. Fig. 4 (a)は明視野像, (b)はこの第二相からの制限視野電子回折パターンである. (c)の回折斑点解析により，この第二相は fcc 構造の格子定 数 $0.424 \mathrm{~nm}$ の $\mathrm{TiN}$ 相であると同定された。

\section{3 形状回復応力}

中央部に溶接金属が位置するように作製した試料を用い て, 前報1)と同様な方法で形状回復応力を測定した.これは

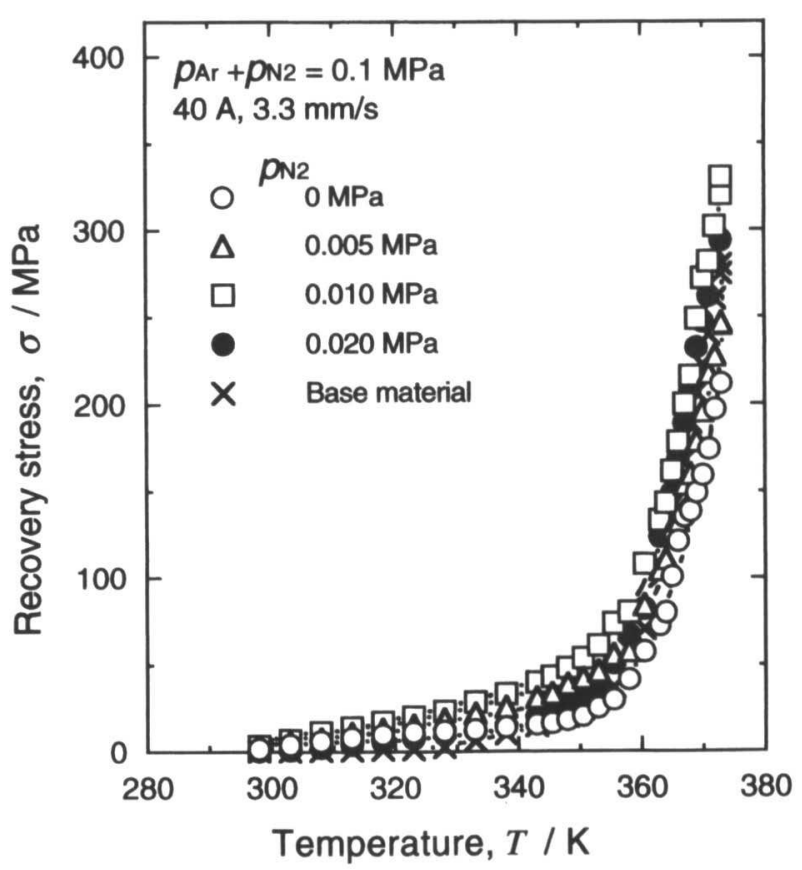

Fig. 5 Relationship between shape recovery stress of weld specimen and temperature $(40 \mathrm{~A})$.

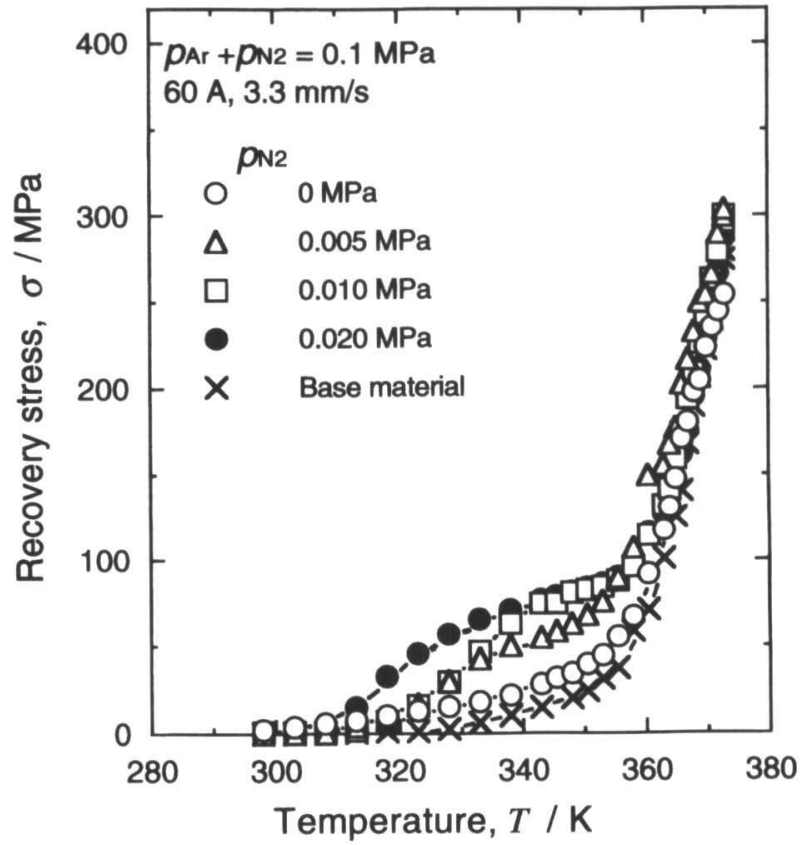

Fig. 6 Relationship between shape recovery stress of weld specimen and temperature $(60 \mathrm{~A})$ 


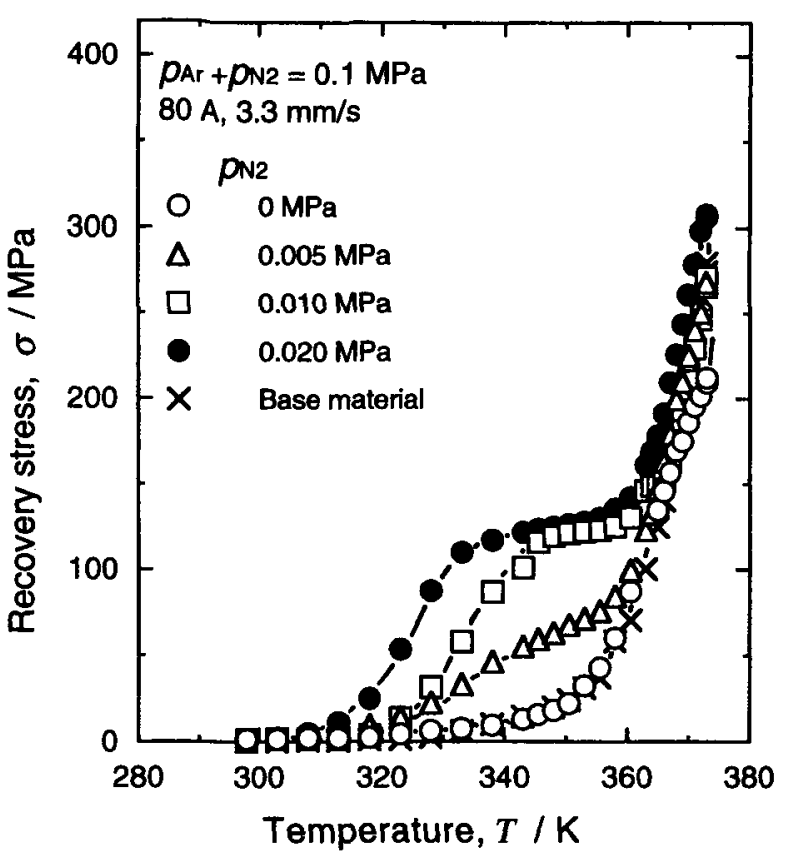

Fig. 7 Relationship between shape recovery stress of weld specimen and temperature $(80 \mathrm{~A})$.

昇温過程で試料が形状回復する力を測定するもので，併せ て温度変化による変態挙動が推定される，尚，この場合に も前報1) と同様に試験後の試料形状は，ほぼ完全に回復す ることが確かめられた。溶接電流が $40 \mathrm{~A}, 60 \mathrm{~A}$ 及び $80 \mathrm{~A} の$ 場合の結果を各々 Fig. 5, Fig. 6 及じ Fig. 7 に示す.

溶接部の無い母材だけの試料では形状回復応力は温度と ともに增加し，高温度になると急激に增加しており，本実 験の材料の基本的な形状回復挙動を示している.

溶接電流が $40 \mathrm{~A}$ の場合には, 各試料とも形状回復応力は 高温度になると急激に増加しており，溶接をしない母材試 料と同様な傾向の変化を示している．また，母材試料及び 溶接試料のいずれにおいても， $372 \mathrm{~K}$ (昇温の最終段階)で 得られる形状回復応力に大きな差はなくほとんど同等であ る.

溶接電流が $60 \mathrm{~A}$ 及び $80 \mathrm{~A}$ の場合には，形状回復挙動は $40 \mathrm{~A}$ の場合とは異なり, 昇温過程の比較的低温度で形状回 復応力が増加した後, 母材試料に近ずくように増加してい る.この様に溶接電流が $40 \mathrm{~A} の$ 場合と $60 \mathrm{~A}$ 及じ $80 \mathrm{~A}$ の場 合で形状回復挙動が異なるのは, $40 \mathrm{~A}$ の場合には吸収され る窒素量が少ないことに加之, 溶接金属が小さく溶接金属 に窒素が吸収されるために起こる変化が, 本測定では十分 に検知されなかった可能性が考えられる。溶接電流が $60 \mathrm{~A}$ 及び80 A の場合の比較的低温度での形状回復応力の増加 は, 雱团気の窒素分圧が高く溶接金属の窒素量が多いほど 低温度で起こる傾向を示している。しかし，各試料の $372 \mathrm{~K}$ で得られる形状回復応力に大きな差は認められない，溶接 電流が $60 \mathrm{~A}$ 及び $80 \mathrm{~A}$ の場合の形状回復举動は, 酸素の影 響を調べた前報の結果 ${ }^{1)}$ とよく似ており，溶接金属の変態
温度が変化して, 昇温過程の比較的低温度で溶接金属が変 態して形状回復が起こり, 続いて溶接金属以外の試料部分 が変態して形状回復した結果であることが示唆される。 こ の昇温過程での形状回復は，マルテンサイト相から母相へ 変態することで起こるので，溶接金属では母相へ変馝開始 温度 ( $A s$ 点) が低温度側に移動したことになる。本実験で は組織観察の結果, TiN が第二相として認められた。 Ti一 $\mathrm{Ni}$ 合金の $\mathrm{Ti}$ 及び $\mathrm{Ni}$ が他の成分と反応して第二相を生成 する場合には, マトリックスの $\mathrm{Ti} / \mathrm{Ni}$ 量比は変化し, $\mathrm{TiN}$ のようにTiとの化合物を生成する場合にはマトリックス の Ti/ $\mathrm{Ni}$ 量比は相対的に低下寸る.また, TiN 相の生成量 が增加すると，この $\mathrm{Ti} / \mathrm{Ni}$ 量比は更に低下する。この $\mathrm{Ti} /$ $\mathrm{Ni}$ 量比が低下すると $\mathrm{Ti}-\mathrm{Ni}$ 合金の変態温度は低下寸る ことが知られている。従って，本実験では溶接金属に吸収 された窒素が $\mathrm{TiN}$ 相を作りマトリックスの $\mathrm{Ti} / \mathrm{Ni}$ 量比を 低下させることが一つの原因となり，溶接金属の $A s$ 点が 低温度側に移動し, 昇温過程の比較的低温度で形状回復応 力が增加し，その後の昇温で溶接金属以外の試料部分が変 態して母材試料に近ずくように形状回復応力が増加したと 考えられる.このように, 形状回復挙動が前報1)の酸素の影 響を調べた結果と似ているのは，生成する第二相がマトリ ックスの Ti を相対的に多く消費ことが酸素の場合と共通 していたためであると考えられる。しかし，Ti-Ni 合金の 変態温度に及ばす窒素の影響を調べた著者らの報告4で は, 変態温度の低下は $\mathrm{TiN}$ 生成によるマトリックスの Ti/ $\mathrm{Ni}$ 量比の変化の他に, 窒素の固溶などの別の効果も考慮し なければならないことが示唆されている。このことは，Ti -Ni 合金の変態温度に及ぼすガスの影響を考える場合, 酸 素と窒素とではやや異なる点である，本実験においては， 吸収された窒素は $\mathrm{TiN}$ を生成し As 点を低下させる他に, マトリックスへの固溶などの効果によりAs 点を低下させ た可能性も考えられる.

窒素がAs 点に及ばす影響を酸素の影響を調べた前報1 と同様にして, Fig. 6 及び Fig. 7 から推定した. As 点に及 ぼす窒素の影響を調べた結果を Fig. 8 に示す。これを直線 で近似して，この直線の傾きからAs 点に及ぼす窒素の影 響を表す実駼式を質量百分率を用いて(2)式に示寸。

$$
A s(\mathrm{~K})=354-335[\text { mass } \% \mathrm{~N}]
$$

これを原子百分率に変換して(2) 式に示す.

$$
A s(\mathrm{~K})=354-88.4 \quad[\mathrm{~mol} \%(\text { at.\%) N] }
$$

この式を用いると $A s$ 点に及ぼす窒素の影響を概算するこ とができる．As点の低下に及ぼす窒素の係数は88.4であ $\eta$, 前報1の酸素の係数一107と比べるとやや小さい值とな る．また, $\mathrm{Ti}-\mathrm{Ni}$ 合金の変態温度に及ぼす窒素の影響をア 一ク溶解法を用いて調べた著者らの研究)では, $M s$ 点に及

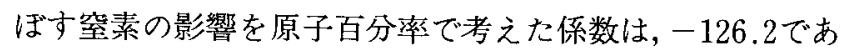
ったＡs 点の変化をこの值と直接比較することはできな いが, 本実験での係数一88.4とはやや異なる。この值の違 いは, 試料の溶融方法が違うためにマトリックスへ固溶す 


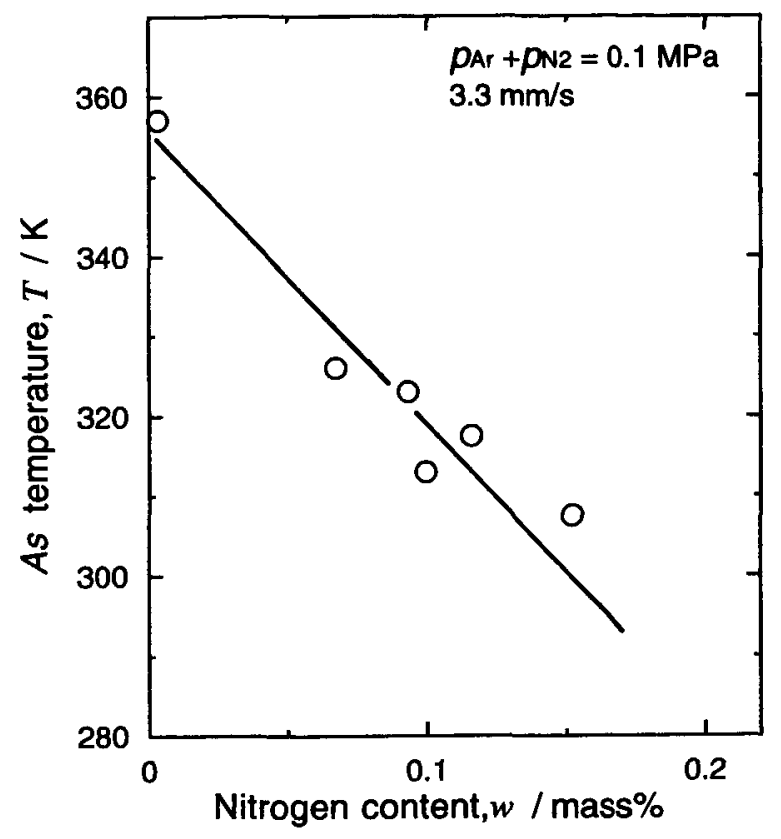

Fig. 8 Effect of nitrogen content on $A s$ temperature of weld metal.

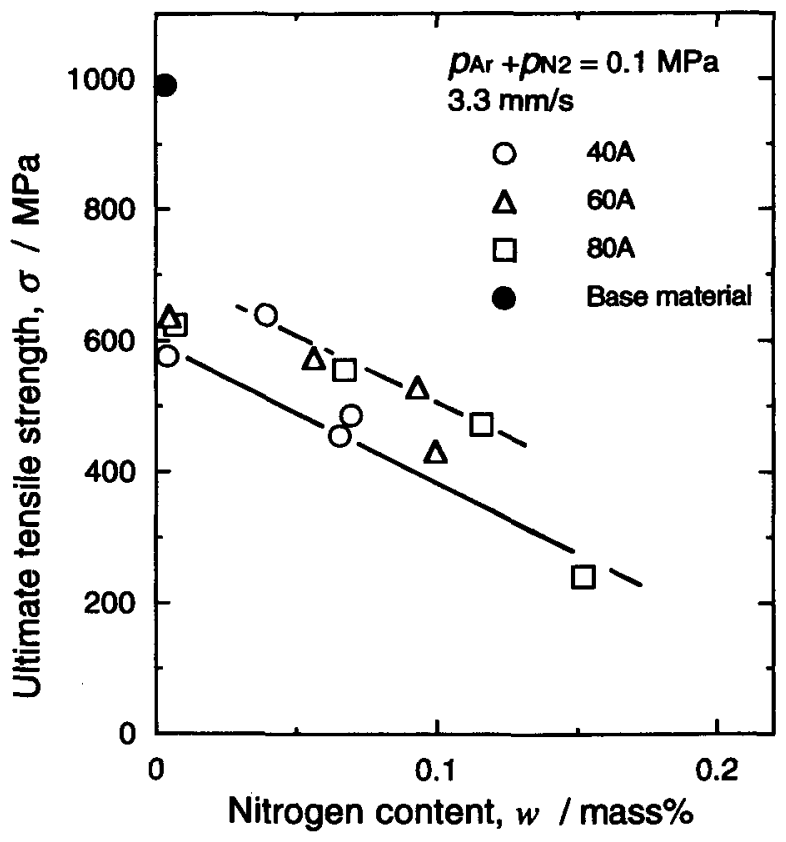

Fig. 9 Effect of nitrogen content on ultimate tensile strength of weld specimen.

る窒素量が異なる可能性などが考えられる.

以上のように，Ti-Ni 形状記憶合金を GTA 溶接して溶 接金属の形状回復力及び形状回復挙動に及ばす窒素の影響 について調べたが，窒素は酸素の場合 ${ }^{1)}$ と同様に形状回復 挙動に大きな影響を及ぼし $A s$ 点を低下させる可能性があ り，この合金を溶接する際には窒素の混入に十分な注意が 必要である。

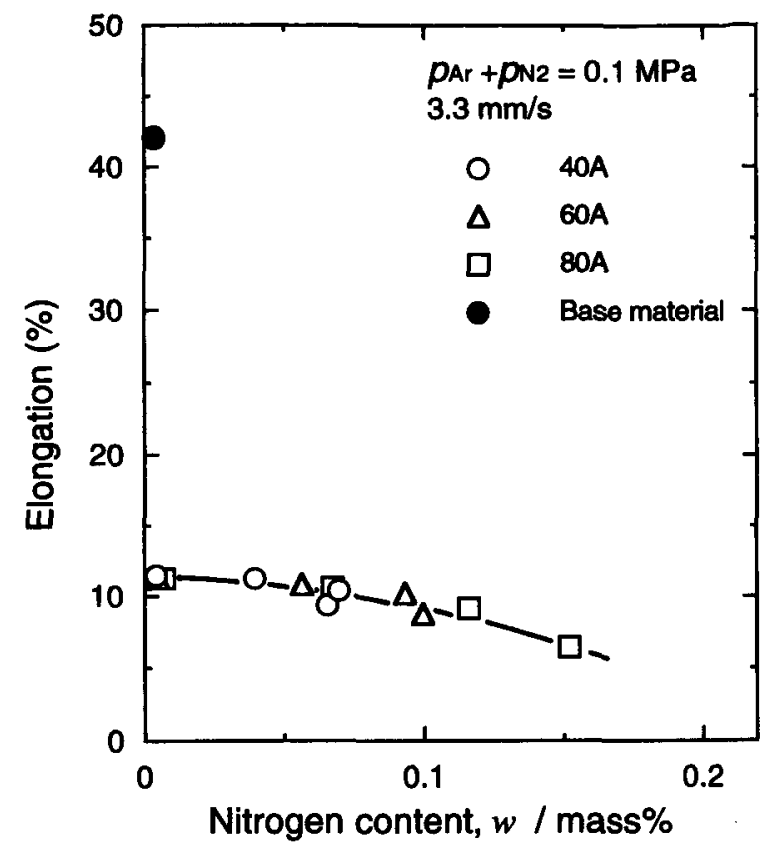

Fig. 10 Effect of nitrogen content on elongation of weld specimen.

\section{4 溶接部の機械的性質}

$\mathrm{Ti}-\mathrm{Ni}$ 合金溶接部の機械的性質に及ぼす窒素の影響を 調べるために，室温での引張試験を前報1)と同じ方法で行 い，引張強さ及び破断伸びを調べた。

溶接試料の窒素量と引張強さの関係を Fig. 9 に示す. 尚，溶接試料はいずれも溶接金属の中央部で破断した。溶 接試料の引張強さは，母材試料に比べて $600 \mathrm{MPa}$ 程度まで 大きく低下し窒素の増加により更に低下寸る，窒素量と破 断伸びの関係を調べた結果を Fig. 10 に示す。溶接試料の 伸びは，母材と比べて急激に減少し，窒素量が増加すると 更に低下し $10 \%$ 以下程度に減少する。このように引張強さ 及び伸び共に減少するのは，酸素の影響を調べた前報1)で も述べたように溶接金属の結晶粒が粗大となり，また第二 相としてTiN を生成するために延性が忌しくなり，脆化す ることが原因と考えられる．以上の上うに $\mathrm{Ti}-\mathrm{Ni}$ 合金を GTA 溶接すると，溶接部の機械的性質は大きく少化する.

\section{4. 結 論}

等原子比近傍組成の $\mathrm{Ti}-\mathrm{Ni}$ 合金を $\mathrm{Ar}-\mathrm{N}_{2}$ 雾团気で GTA 溶接し, 溶接部の窒素吸収挙動, 金属組織, 形状記憶 挙動及び機械的性質に及ぼす窒素の影響を調へ，次の結果 を得た。

(1) 溶接金属の窒素量は，雾囲気の窒素分圧及び溶接電 流の増加により増加する。

（2）溶接ビード幅は，溶接電流及び霩囲気の窒素分圧の 增加により增加する傾向を示す，溶接金属が窒素を吸 
収すると，金属組織に第二相が観察され，窒素量が増 加すると第二相の量は増加する。この第二相は， TiN と同定された。

（3）䇪素量が異なる溶接試料においても形状回復力は, 母材と同等で大きな差は見られない，溶接金属の窒素 量が多くなるに従い As 点が低下するために，接合試 料は母材と異なる形状回復挙動を示す.

（4）溶接金属の機械的特性は，酸素の場合と同様に大き く低下する，引張強さは母材の60\%程度まで，伸びは $1 / 4$ 程度に減少し，窒素を吸収するとこれらは更に低 下する。

$$
\text { 謝 辞 }
$$

終に臨み，本実験遂行にご協力いただいた松永英子工学 修士ならびに東北大学工学部本田明技術専門職員に感謝い たします。

\section{参考 文 献}

1）佐藤嘉洋, 粉川博之, 桑名 武, 佐藤正一：Ti- $\mathrm{Ni}$ 形状記憶合金 溶接部の形状回復及び引張特性に及ほす酸素の影響, 溶接学会 論文集，18-2(2000)，485-521.

2）鈴木雄一, $\mathrm{Ti}-\mathrm{Ni}$ 基形状記憶および超弾性合金の実用化状況, ま てりあ, 36-12 (1997), 1132-1138.

3) A.G. Rozner, E.F. Heintzelman, W.J. Buehler and J.V.Gilfrich : Effect of Addition of Oxygen, Nitrogen and Hydrogen on Microstructure and Hardness of Cast TiNi Intermetallic Compound, ASM Trans. Quart., 58-3 (1965), 415-418.

4）佐藤募洋, 高橋英則, 粉川博之, 桑名 武, 山内 清, 佐藤正一： $\mathrm{Ti}-\mathrm{Ni}$ 形状記憶合金の変態温度に及ぼす窒素の影響, 溶接学会 論文集, 17-1 (1999)，78-85.

5）守護嘉朗, 山内 清, 宮川 量, 本間敏夫：TiNi 合金の Ms 温 度抢よび機械的性質に及ぼす炭素の影響，(東北大学) 選研栄報, 38-1 (1982), 11-20.

6）守護嘉朗, 花田修治, 本間敏夫：TiNi 合金のマルテンサイト変 態に及ほす酸素の影響ならびに欠陷構造の同定, (東北大学) 選 研栄報, 41-1 (1985), 23-34. 